Для протеїнів сироватки молока притаманна фракційна специфічність їх біологічної дї̈ та здатності утворювати в процесах протеолізу і травлення біоактивні пептиди, які позитивно впливають на різні фізіологічні системи організму. Перспективи виробництва $i$ застосування протеїнових фракцій з сироватки молока пов'язані з необхідністю контролю за їх складом.

Для створення методики експрес-аналізу фракційного складу протеїнів сироватки молока проведено порівняльний аналіз електрофоретичних систем, які раніше використовувалися для аналізу протеїнів молока. Це анодна система диск-електрофорезу в присутності додецилсульфату натрію, система дискелектрофорезу Девіса для кислих протеїнів у нативних умовах, система в однорідному поліакриламідному гелі в присутності сечовини. За основу для аналізу протеїнів сироватки молока була взята система диск-електрофорезу Девіса для кислих протеїнів в нативних умовах. Для адаптації иієї системи до вимог експрес-аналізу з їі складу було вилучено концентруючий поліакриламідний гель $і$ зменшено концентрацію розділяючого гелю. Для забезпечення високої ефективності розділення протеїнових фракцій була використана різниия у складі іонів електродного буферу $і$ буферу для поліакриламідного гелю. Це дозволяє зберегти ефект концентрування протеїнів зразку сироватки на периих етапах електрофорезу. 3 допомогою гомогенних маркерних протеїнів ( $\beta$-лактоглобулін $і$ альбумін сироватки), встановлено розміщення основних фракцій протеїнів сироватки молока на електрофореграмах.

В результаті проведених досліджень запропонована доступна електрофоретична система в пластинках однорідного поліакриламідного гелю для серійного експрес-аналізу фракційного складу протеїнів сироватки молока. Система дозволяє надійно ідентифікувати чотири протеїнові фракцї ( $\alpha-L A, \beta-L G, B S A$ та IG). Про хорошу відтворюваність методу свідчать близькі середні значення $і$ стандартні відхилення вмісту иих фракиій у 15-ти пробах сироватки однієї партії молока, отримані на

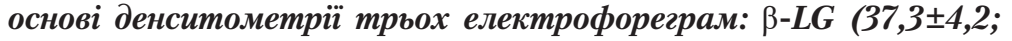
$36,5 \pm 2,8 ; 38,3 \pm 2,7), \alpha-L A(15,8 \pm 1,5 ; 15,8 \pm 1,3 ; 16,4 \pm 1,1), B S A$ $(8,2 \pm 1,1 ; 8,0 \pm 1,0 ; 9,4 \pm 1,1), I G(17,6 \pm 1,9 ; 17,4 \pm 1,5 ; 16,8 \pm 1,5)$.

Запропонований метод може бути корисним для оперативної іӘентифікації основних протеїнових фракцій сироватки молока, які є попередниками біологічно активних пептидів

Ключові слова: фракції протеїнів сироватки молока, електрофорез в поліакриламідному гелі, експрес-аналіз, денситометрія

\title{
ELECTROPHORETIC SYSTEM FOR EXPRESS ANALYSIS OF WHEY PROTEIN FRACTIONS
}

V. Yukalo

Doctor of Biological Sciences, Professor Department of Food Biotechnology and Chemistry

Ternopil Ivan Puluj

National Technical University

Ruska str., 56, Ternopil, Ukraine, 46001

E-mail: biotech@tu.edu.te.ua

K. Da t s y s h y $n$

Assistant

Department of Food Biotechnology and Chemistry

Ternopil Ivan Puluj

National Technical University

Ruska str., 56, Ternopil, Ukraine, 46001

E-mail: katkostyuk3103@gmail.com

L. S t oroz h

$\mathrm{PhD}$

Department of Food Biotechnology and Chemistry

Ternopil Ivan Puluj

National Technical University

Ruska str., 56, Ternopil, Ukraine, 46001

E-mail: storozh@tntu.edu.ua

\section{Introduction}

Whey proteins are one of the two basic milk protein fractions. They comprise about $20 \%$ of all milk proteins and are valuable by their amino acid composition. In most cases, in food technologies, these proteins are used in the whey composition without obtaining individual fractions [1]. The main source of them are different types of milk whey (sour milk cheese, cheese, casein, ultrafiltrate), which is a by-product. The concentration of proteins in whey is low ( 0.6-0.9\%). Therefore, its processing is complex, ree quires expensive equipment, significant energy costs and yields little profit in food production.

The discovery, in recent decades, of bioactive peptides with a wide range of biological effects in the composition of basic whey proteins provides new opportunities for the processing of whey proteins. This may be the creation of valuable natural functional ingredients based on biologically active peptides [2]. Peptides with a certain biological activity are isolated from different fractions [3]. In this regard, the task emerged to develop industrial methods for obtaining separate milk whey protein fractions, which are precursors of bioactive peptides. Another important task is to create a reliable, accessible and effective express method for analyzing the fractional composition of whey proteins. Existing methods are too complicated or expensive and time-consuming to analyze large amounts of whey protein samples in manufacturing laboratory conditions [4].

The development of an effective express method for the analysis and identification of milk whey protein fractions 
is an actual task. Such a method may also be important in establishing the authenticity of the composition of whey-containing protein products.

\section{Literature review and problem statement}

In all whey types, the following basic proteins are present: $\beta$-lactoglobulin ( $\beta$-LG), $\alpha$-lactalbumin $(\alpha$-LA), serum albumin (BSA), immunoglobulin (IG), and also two important minor proteins - lactoferrin (LF) and the secretory component (SC) [5]. In cheese whey, glycomacropeptide (GMP), which is formed as a result of the $\kappa$-casein splitting by milk enzymes, is present in significant amounts [6]. In addition, several hundreds of different minor proteins have been found in milk whey using modern proteomic methods. Their functions and origin are not fully established [7].

Practical interest to milk whey protein fractions is associated with their biological function. In the first place, this concerns to immunoglobulins and lactoferrin [8, 9]. Also, the ratio of whey protein fractions is important during creating substitutes of female milk [1]. In recent decades, a new promising direction emerged in using whey proteins, in connection with the discovery of biologically active peptides (BAP) in their composition. It is established that the basic whey proteins are precursors of more than a hundred different BAPs. These BAPs can have a positive effect on the immune system (immunomodulatory and antimicrobial peptides), the nervous system (agonists of opioid receptors), the cardiovascular system (antihypertensive and hypocholesterolemic peptides), the digestive system (regulators of intestinal motility, appetite regulators) [10]. Also peptides with anti-carcinogenic and antioxidant effects have been discovered [11,12]. In many cases, these peptides are resistant to digestive proteases, can penetrate the bloodstream and exhibit their biological effects. It is important that the fractional specificity is characteristic for the BAP formation $[3,10]$. It is expedient to obtain a BAP of a certain biological action from individual whey protein fractions. In this regard, an accessible and effective method for the express analysis and identification of milk protein fractions is necessary for the development of methods for obtaining proteins-precursors of BAP from milk whey proteins, as well as for their industrial production.

Chromatographic and electrophoretic methods are most commonly used in laboratory researches for the analysis of whey proteins [4]. The structure, composition and properties of milk whey proteins allow using two types of chromatography: gel filtration and ion-exchange chromatography. In the case of gel filtration, this is facilitated by a significant difference in molecular weights ( $\alpha$-LA 14,178 Da, $\beta$-LG - 18,363 Da, BSA - 66,399 Da, LF $76,110 \mathrm{Da}$ and IG $->150,000 \mathrm{Da}$ ) and also the globular structure of molecules. Differences in the values of isoelectric points are important for ion-exchange chromatography $(\alpha-\mathrm{LA}-4.2 ; \beta-\mathrm{LG}-5.13$; BSA -4.7 ; IG -5.5 and LF - 8.8). Good solubility and absence of whey protein aggregates are also positive properties for chromatographic analysis [13]. The main disadvantages of chromatographic analysis methods are: expensive equipment and reagents for both types of chromatography; relatively low gel filtration efficiency; the impossibility of simultaneous comparative analysis of sample series. Therefore, they can not be used for the express analysis.

An effective method for whey protein analysis is polyacrylamide gel (PAG) electrophoresis. One-dimensional electrophoresis in columns or slabs of PAG allows reliable identification of all basic and some minor fractions [14, 15]. Variants of two-dimensional electrophoresis are effectively used in milk whey proteomics and can detect tens and even hundreds of minor protein fractions [7].

The International Committee on the nomenclature and methodology of milk proteins recommends the use of a one-dimensional anode disc electrophoresis system with sodium dodecyl sulfate for the analysis of whey proteins [5]. In this case, such fractions as $(\alpha-\mathrm{LA}, \beta-\mathrm{LG}, \mathrm{BSA}, \mathrm{IG}$ and LF) can be identified. In our laboratory, the modified B. Davis disc electrophoresis analytical system for acidic and neutral proteins in native conditions was also successfully applied for the analysis of whey proteins [15]. In both cases, high resolution was achieved by the use of stacking PAG. The main disadvantages of analytical disc electrophoretic systems are the necessity to prepare a large number of reagents and form two types of PAG. This complicates the analysis and makes it long-lasting. In general, the disc electrophoresis systems do not meet the express analysis requirements, but electrophoretic methods do not require expensive equipment, are available and can be adapted for serial and comparative analysis of milk whey proteins. Such an electrophoretic system in a homogeneous PAG was previously developed for the analysis of milk casein complex proteins [16]. It allows detecting all major casein fractions for 45 minutes. Such an electrophoretic system for express analysis of the whey protein fractional composition is absent, up today, and needs to be developed.

\section{The aim and objectives of the study}

The aim of the work was the selection and adaptation of the electrophoretic system for the express analysis of the fractional composition of whey proteins.

To achieve this aim, the following objectives were accomplished:

- to select the basic version of the electrophoretic system on the basis of a comparative analysis of known methods of milk protein electrophoretic research;

- to adapt the selected variant of the electrophoretic system to express analysis of the whey protein fractional composition;

- to compare the electrophoregrams of whey proteins with the electrophoregrams of milk casein complex proteins;

- to estimate the reproducibility of the method based on the analysis of different whey samples.

\section{Materials and methods of electrophoretic, densitometric, chromatographic and spectrophotometric studies of whey proteins}

4. 1. Materials, reagents and equipment used in the study

Fresh skimmed milk was used. Milk skimming was carried out twice on an OPN-8 centrifuge $(4,000 \mathrm{rp} / \mathrm{m}$, 
10 minutes). The casein complex protein preparation was obtained by isoelectric point precipitation [17]. Whey was isolated by centrifugation of skimmed milk $(5,000 \mathrm{rp} / \mathrm{m}$, 10 minutes) after isoelectric precipitation of caseins. The procedure was repeated twice. Blood serum albumin (BSA) from Sigma (Germany) company and cow's milk $\beta$-lactoglobulin were used as marker proteins in electrophoretic researches. Homogeneous $\beta-\mathrm{LG}$ was isolated from whey by repeated gel filtration on a column of Sephadex G-100 [18]. Sephadex from Pharmacia (Sweden) company was used for gel filtration. Buffer solutions and polyacrylamide gels for electrophoresis were prepared using reagents from Reanal (Hungary) company and domestic high-purity reagents.

Electrophoretic research was carried out on the Reanal company apparatus (for PAG columns) and the Studier type apparatus (for PAG slabs). Spectrophotometric determination of whey protein and casein complex protein concentrations was performed on an SF-46 spectrophotometer. In this case, previously found absorption coefficients $\left(\mathrm{D}_{1 \% / 1 \mathrm{~cm}}\right)$ were used: 12.3 - for whey proteins; 9.6 - for $\beta$-LG; 6.7 - for BSA; 8.2 - for casein complex proteins. Gel filtration was carried out on the columns of the Reanal company liquid chromatography kit.

4. 2. Methods of polyacrylamide gel electrophoresis of milk proteins and densitometry of electrophoregrams

The B. Davis disc electrophoresis system in native conditions for acidic and neutral proteins [15], analytical and express variants of the homogeneous PAG electrophoretic system with urea for the analysis of casein complex proteins $[15,16]$ were used for selecting the electrophoretic system for whey protein express analysis.

Express electrophoresis of whey proteins was carried out in PAG slabs. In this case, electrophoresis conditions and buffer composition were used such as in the disc electrophoresis in native conditions for acidic and neutral proteins. The composition of homogeneous PAG of the electrophoretic system for express analysis is shown in Table 1.

The construction of densitograms for quantitative processing of electrophoregrams was carried out by using the image reading function imread [19].

The mathematical and statistical processing of the research results was performed using the Microsoft Office Excel 2007 program packages. The average value and standard deviation of the comparative whey protein fraction contents were determined.

\section{Results of electrophoretic researches of whey proteins}

5. 1. Selection of the basic electrophoretic system for express analysis of the fraction composition of whey proteins

Whey protein electrophoresis was performed using known electrophoretic systems that were previously used for the analysis of milk proteins for selecting the basic method for the express analysis. The results of the analysis are shown on the electrophoregram (Fig. 1). A typical picture of whey protein separation by analytical disc electrophoresis in native conditions in PAG columns can be seen on the electrophoregram (Fig. 1(1)). All basic protein fractions ( $\beta$-LG, $\alpha$-LA, BSA, IG) and proteose-peptone fraction (PPF) have been identified. Individual whey proteins obtained by repeated gel filtration on Sephadex G-100 were used for identification. Also, whey was analyzed by a method developed for the express analysis of milk proteins, in particular, casein complex proteins (Fig. 1 (2)), based on the analytical homogeneous PAG anode system with urea (Fig. 1 (3)). Such system allows us to reliably identify all casein fractions that differ in the primary structure $\left(\alpha_{\mathrm{S} 1}-\mathrm{CN}, \alpha_{\mathrm{S} 2}-\mathrm{CN}, \beta-\mathrm{CN}\right.$ and $\left.\kappa-\mathrm{CN}\right)$. However, the bands of whey proteins in the electrophoregram obtained in this system are blurred and badly identified (Fig. 1 (4)).

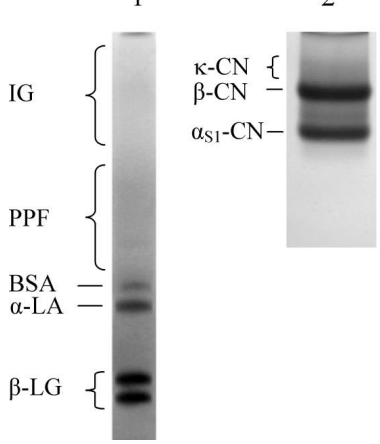

3

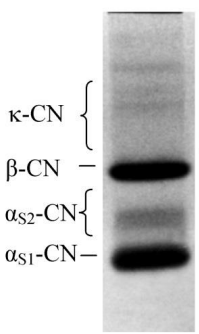

4 IG BSA $\alpha$-LA \{ $\beta-L G$
Fig. 1. Electrophoregrams of milk proteins in different electrophoretic systems: 1 - whey proteins in the analytical disc electrophoretic system; 2 - milk casein complex proteins in the express system of homogeneous PAG with urea; 3 - milk casein complex proteins in the analytical system of homogeneous PAG with urea; 4 - whey proteins in the express system of homogeneous PAG with urea

Table 1

Composition of polyacrylamide gel for express analysis

\begin{tabular}{|c|c|c|c|}
\hline Solutions & Part of the solution in the PAG (volume) & Component & Amount \\
\hline \multirow{3}{*}{ Gel components } & \multirow{3}{*}{2} & acrylamide & $14 \mathrm{~g}$ \\
\hline & & N,N'methylenebisacrylamide & $0.4 \mathrm{~g}$ \\
\hline & & Water & to $50 \mathrm{~cm}^{3}$ \\
\hline \multirow{4}{*}{$\begin{array}{l}\text { Buffer for gel and } \\
\text { catalyst }\end{array}$} & \multirow{4}{*}{1} & $1 \mathrm{H} \mathrm{HCl}$ & $24 \mathrm{~cm}^{3}$ \\
\hline & & tris (hydroxymethyl)aminomethane & $18.3 \mathrm{~g}$ \\
\hline & & $\mathrm{N}, \mathrm{N}, \mathrm{N}^{\prime}, \mathrm{N}^{\prime}$ tetramethylethylenediamine & $0.115 \mathrm{~cm}^{3}$ \\
\hline & & Water & to $50 \mathrm{~cm}^{3}$ \\
\hline \multirow{2}{*}{ Initiator solution } & \multirow{2}{*}{5} & ammonium persulphate & are selected experimentally \\
\hline & & Water & to $25 \mathrm{~cm}^{3}$ \\
\hline
\end{tabular}


The disc electrophoretic system in native conditions was chosen on the basis of the obtained results as the basic for further researches. Then, a comparative analytical PAG disc electrophoresis of three whey samples, a sample of the homogeneous fraction of $\beta-\mathrm{LG}$, obtained by repeated gel filtration, and BSA fraction was performed. The results are shown on the electrophoregram (Fig. 2, $a$ ). All basic fractions that are separated in this system were identified using marker proteins. The efficiency of separation is confirmed by the densitogram of the second sample of whey proteins (Fig. 2, $b$ ).
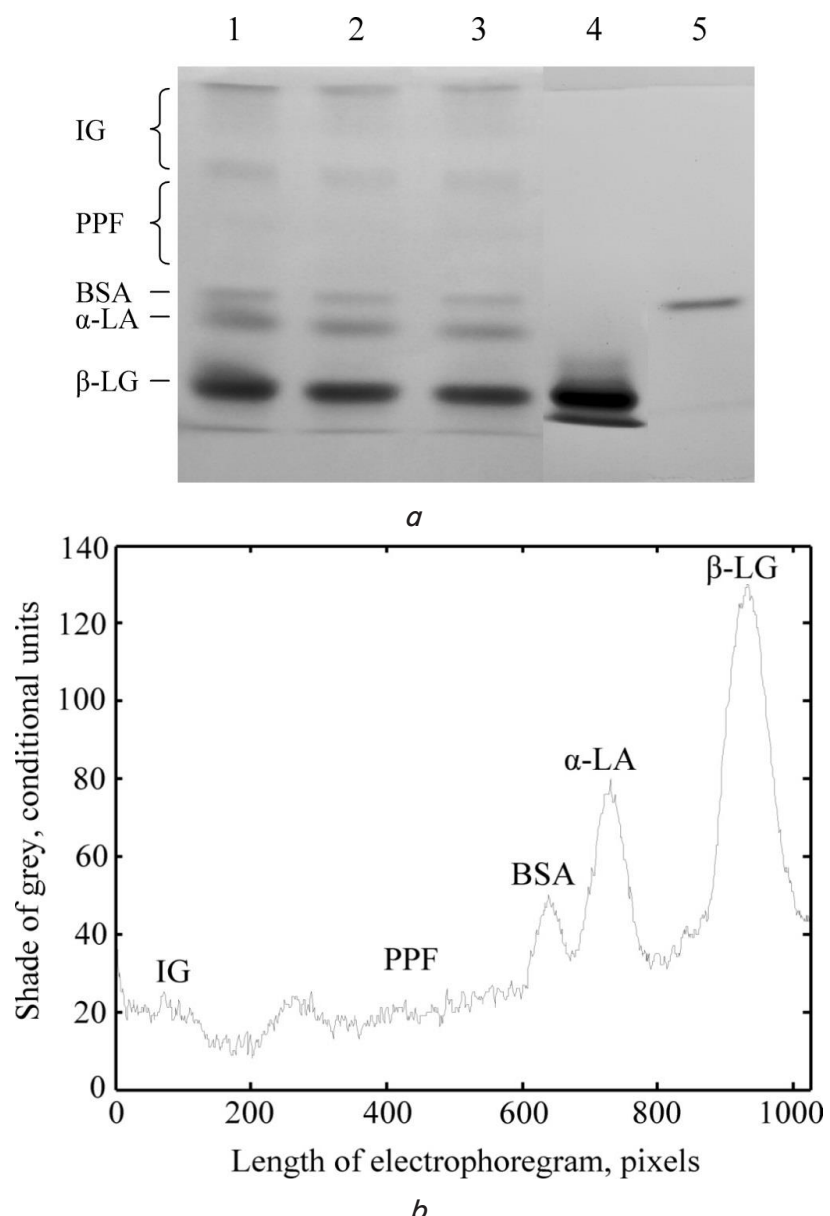

Fig. 2. Electrophoregram and densitogram of whey proteins obtained by analytical disc electrophoresis:

$a$ - electrophoregram of three whey samples (1-3), $\beta$-LG

(4) and BSA (5); $b$-densitogram of the whey sample 2 electrophoregram

5. 2. Adaptation of the electrophoretic system for express analysis of whey protein fraction composition

A separating gel of the analytical disc electrophoresis system with a concentration of acrylamide reduced by $0.5 \%$ was used to create an express electrophoretic system. The duration of electrophoresis is also reduced to 35 minutes. Also, changes in the processes of fixing and staining of the gel slabs have been made. Staining and fixing are carried out simultaneously for 3 minutes. This reduces the duration of destaining. The basic protein fractions can be identified already after 25-30 minutes while using intense destaining. The results of the express analysis of three samples of whey and casein complex proteins are shown in Fig. 3. As can be seen on the electrophoregrams, the express system allows high-quality separation of the basic whey protein fractions. Three from four basic casein fractions, $\alpha_{\mathrm{S} 1}-\mathrm{CN}, \beta-\mathrm{CN}$ and $\alpha_{\mathrm{S} 2}$-CN mixture, can be identified on the electrophoregram. The $\kappa-\mathrm{CN}$ fractions are blurred. The densitogram (Fig. 3, b) confirms the high efficiency of the express electrophoretic system in relation to whey proteins.

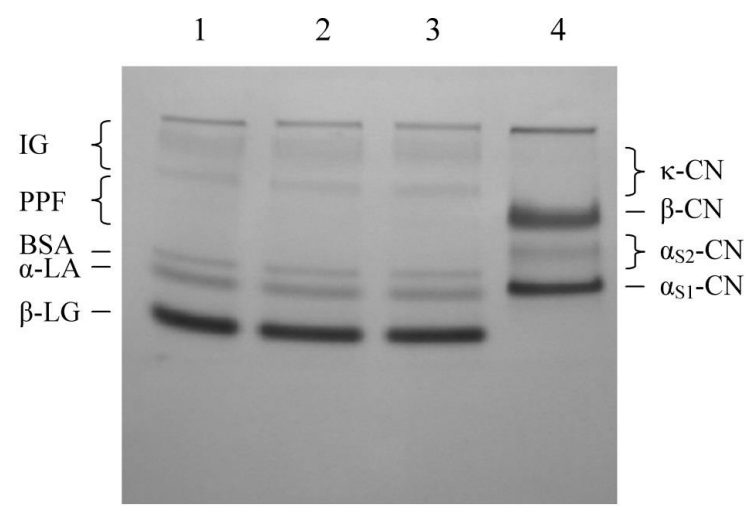

$a$

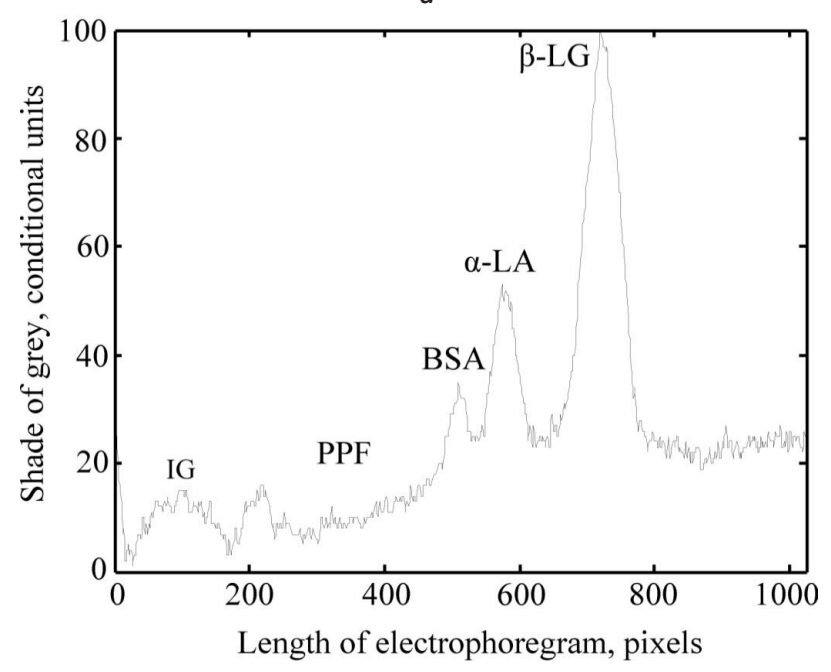

b

Fig. 3. Electrophoregram and densitogram of milk proteins obtained in the proposed system for homogeneous PAG slabs: $a$ - electrophoregram of three samples of whey (1-3) and casein complex proteins (4); $b$ - densitogram of the whey sample 2 electrophoregram

\section{3. Comparison of whey protein and casein complex} protein electropherograms

It is known that a $4.5 \mathrm{M}$ solution of urea promotes the dissolution of milk protein samples containing caseins. 4.5 $\mathrm{M}$ urea was added to the gel composition to verify the effect of urea on the express electrophoresis result. The analysis results of three samples of whey and casein complex proteins in the presence of $4.5 \mathrm{M}$ urea are shown in Fig. 4. It is necessary to note the increasing clarity of casein fractions on the electrophoregram. Whey protein bands became blurred and the ratio of protein fractions changed.

All previous electrophoregrams were obtained using Amido black 10B dye. In most modern methods of protein electrophoresis, a more sensitive dye, Coomassie G-250, is used. Fig. 5 shows an express electrophoregram of three samples of whey and casein complex proteins, stained with Coomassie G-250. The protein band staining is more 
intense in the result, but the process of destaining became longer. It should be noted that additional bands of minor fractions appeared on the whey protein electrophoregram.

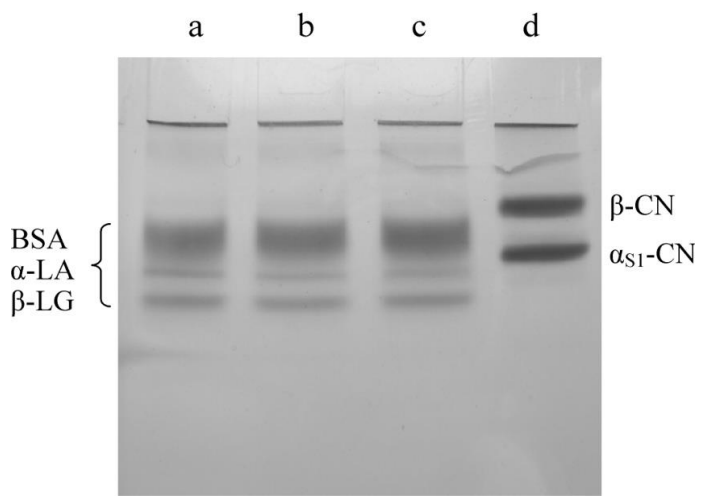

Fig. 4. Electrophoregram of milk proteins, obtained in the proposed system for homogeneous PAG slabs with $4.5 \mathrm{M}$ urea: $a-$ milk whey sample $1 ; b-$ milk whey sample 2 ; $c$ - milk whey sample 3 ; $d$ - casein complex proteins

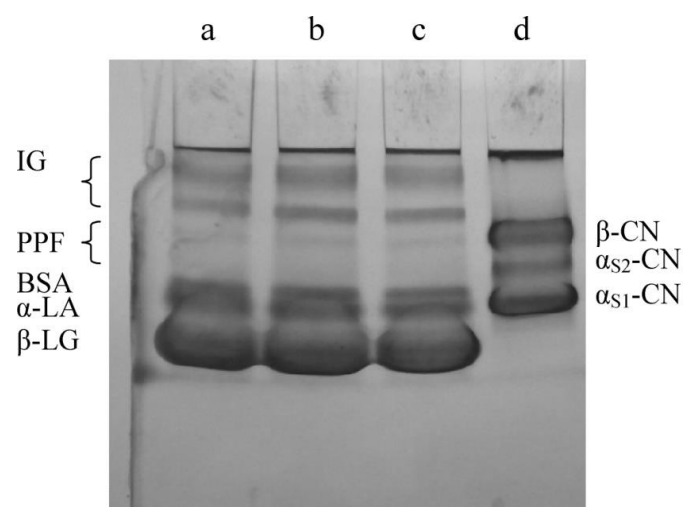

Fig. 5. Electrophoregram of milk proteins, obtained in the proposed system for homogeneous PAG slabs and stained by Coomassie G-250: a - whey sample 1; b - whey sample 2; $c-$ whey sample $3 ; d-$ casein complex proteins

5. 4. Checking the electrophoretic system reproducibility during the whey protein fraction composition analysis

The reproducibility of the method was estimated by the number of protein fractions in different milk batches, as well as by the relative distribution of protein content in the fractions of different samples of one batch. Characteristic distribution of the four basic protein fractions ( $\beta-\mathrm{LG}$, $\alpha$-LA, BSA and IG) and the proteose-peptone fraction was obtained in all analyzed milk batches (10 batches), as shown in the electrophoregrams (Fig. 3, a and Fig. 6). It is necessary to analyze samples from one milk batch to check the reproducibility of the four fractions relative content. This eliminates the effect of differences in the composition of whey proteins from different milk batches. A typical electrophoregram of five whey samples from one milk batch is shown in Fig. 6. A densitogram for each sample was constructed (Fig. 7), the average value and standard deviation of the relative content of protein fractions were determined (Table 2).

The average values of $\alpha$-lactalbumin and BSA, shown in Table 2, are well agreed to the known literature data. Differences in the content of $\beta$-lactoglobulin and immunoglobulins, obviously, are due to the peculiarities of their interaction with the dye. In general, the average values of the fractions relative content and standard deviations (Table 2) testify about the good reproducibility of the method. This may be the basis for creating a quantitative version of this express method. The densitograms construction can be used for quantitative assessment of the whey protein fractions homogeneity in the process of their obtaining.

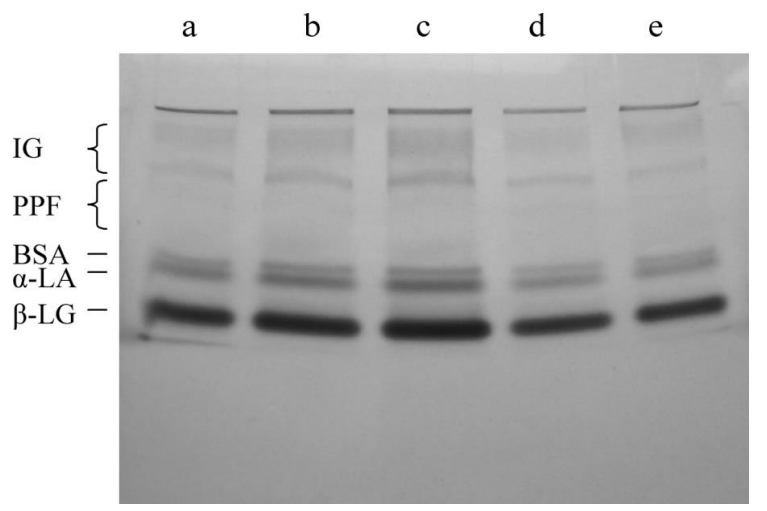

Fig. 6. Electrophoregram of whey samples, obtained in the proposed system for homogeneous PAG slabs : a - sample 1; b - sample 2; c - sample 3; d- sample 4; e - sample 5

Table 2

Content of protein fractions of 15 whey samples

\begin{tabular}{|c|c|c|c|c|}
\hline \multirow{2}{*}{$\begin{array}{l}\text { No. of } \\
\text { the whey } \\
\text { sample }\end{array}$} & \multicolumn{4}{|c|}{ Whey protein fractions } \\
\hline & IG & BSA & $\alpha$-LA & $\beta$-LG \\
\hline \multicolumn{5}{|c|}{ PAG slab No.1 } \\
\hline 1 & 16 & 8 & 15 & 39 \\
\hline 2 & 15 & 10 & 18 & 43 \\
\hline 3 & 19 & 8 & 16 & 39 \\
\hline 4 & 19 & 8 & 16 & 35 \\
\hline 5 & 19 & 7 & 14 & 32 \\
\hline $\begin{array}{c}\text { Average } \\
\text { value } \\
(M \pm m \\
n=5)\end{array}$ & $17.6 \pm 1.9$ & $8.2 \pm 1.1$ & $15.8 \pm 1.5$ & $37.3 \pm 4.2$ \\
\hline \multicolumn{5}{|c|}{ PAG slab No.2 } \\
\hline 1 & 17 & 9 & 16 & 42 \\
\hline 2 & 18 & 7 & 14 & 36 \\
\hline 3 & 19 & 7 & 17 & 37 \\
\hline 4 & 15 & 9 & 15 & 35 \\
\hline 5 & 18 & 8 & 17 & 39 \\
\hline $\begin{array}{c}\text { Average } \\
\text { value } \\
(M \pm m \\
n=5)\end{array}$ & $17.4 \pm 1.5$ & $8.0 \pm 1,0$ & $15.8 \pm 1.3$ & $36.5 \pm 2.8$ \\
\hline \multicolumn{5}{|c|}{ PAG slab No.3 } \\
\hline 1 & 15 & 9 & 16 & 40 \\
\hline 2 & 17 & 8 & 18 & 42 \\
\hline 3 & 16 & 10 & 17 & 37 \\
\hline 4 & 17 & 11 & 16 & 35 \\
\hline 5 & 19 & 9 & 15 & 39 \\
\hline $\begin{array}{c}\text { Average } \\
\text { value } \\
(M \pm m \\
n=5)\end{array}$ & $16.8 \pm 1.5$ & $9.4 \pm 1.1$ & $16.4 \pm 1.1$ & $38.3 \pm 2.7$ \\
\hline
\end{tabular}




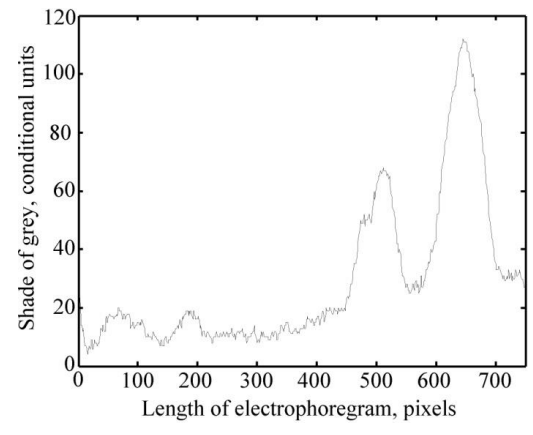

a
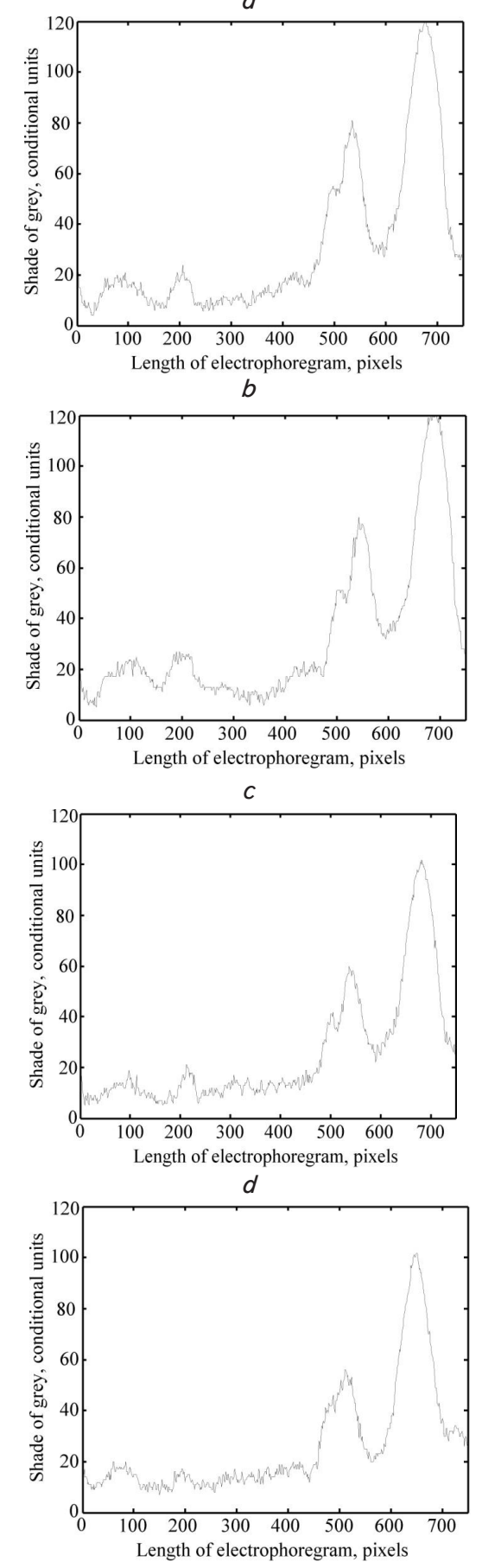

e

Fig. 7. Densitograms of whey samples electrophoregrams obtained in the proposed system for homogeneous PAG

slabs: $a$ - sample $1 ; b$ - sample $2 ; c$ - sample 3 ; $d$ - sample 4 ; $e$ - sample 5

\section{Discussion of the whey protein fraction composition} express analysis results

Two electrophoretic systems of disc electrophoresis (in the presence of SDS or in native conditions) and one system of homogeneous PAG in the presence of urea are used in various modifications for the analysis of the milk protein fraction composition [5, 14, 15, 20]. On the basis of a homogeneous PAG system with urea, a method for milk casein complex protein express analysis was developed [16]. Preliminary analysis of these methods (Fig. 1) shows that they cannot be used for the simultaneous analysis of all milk proteins. Two groups of milk proteins (caseins and whey proteins) significantly differ in their structure and properties [5]. Therefore, the express analysis on the basis of an electrophoretic system of homogeneous PAG with urea effectively separates casein complex proteins, but is not suitable for whey proteins.

Both disc electrophoresis systems are complex and require the preparation of a large number of reagents. Also, while using disc electrophoresis with SDS, all whey proteins are denatured. It is known that casein protein fractions anomalously bind SDS [13]. This leads to a disparity between their electrophoretic mobility and molecular weight. In whey samples with caseins they will be difficult to identify.

In this connection, the system of disc electrophoresis in native conditions for acidic proteins was used as the basis [15]. The analytical version of this system in the PAG slabs provides reliable identification of the basic whey protein fractions and makes it possible to compare different samples with their simultaneous separation (Fig. 2). Its main disadvantage is the disc electrophoretic system complexity. Changes were made for its adaptation to the conditions of express analysis. The stacking PAG with the appropriate buffer was removed from the system. The concentration of the separating gel is reduced by $0.5 \%$. In this case, the composition of the electrode buffer and the buffer for the separating gel was unchanged. This made it possible to significantly simplify the electrophoretic system and at the same time provided a high separation efficiency by saving the effect of concentration of sample proteins (Fig. 3). The role of the stacking gel, in this case, is played by the upper part of the separating gel. This occurs as follows. At the beginning of electrophoresis, whey protein molecules and glycine ions from the electrode buffer move into the separating gel. In the case of disc electrophoresis, proteins and ions initially move into the stacking gel [21]. Then, the change of the $\mathrm{pH}$ at the boundary between the upper electrode buffer and the separating PAG accelerates the movement of glycine ions. This leads to the formation of the interface between $\mathrm{Cl}^{-}$and glycine ions, which move to the anode in the upper part of the separating PAG. An area with high electric field strength is formed, outside the ion interface where the sample protein concentration occurs. This process can be observed in $\sim 7$ minutes after the start of electrophoresis in the express system.

To simplify the system, considering the small volume of whey samples, we did not use a special sample buffer. The following results (Fig. 5) showed that staining can be done with the help of more accessible and cheap Amido black $10 \mathrm{~B}$ dye. All basic whey protein fractions are detected with it. Additional unidentified bands of minor protein fractions appear on the electrophoregram (Fig. 5) while using a more 
sensitive Coomassie G-250 dye. However, the procedure of staining and distaining is much faster with Amido black 10B. Electrophoretic discoloration of gel slabs can be used to accelerate the process of distaining.

It is known that urea can improve the solubility of dry milk samples, especially when caseins are present [21]. However, the addition of $4.5 \mathrm{M}$ urea into the sample and PAG significantly reduced the effectiveness of fractionation of whey proteins (Fig. 4). Obviously, their partial denaturation takes place. This is indicated by the simultaneous presence of characteristic bands for $\beta-\mathrm{LG}$ and $\alpha$-LA, as well as new blurred protein bands on electrophoregrams. However, the quality of casein fractionation increases in this case (Fig. 4,e).

Simultaneous express analysis of 15 whey samples showed good reproducibility by the shape of protein bands (Fig. 6) and the content of the basic protein fractions (Table 2).

The proposed electrophoretic system makes it possible to quickly analyze the fractional composition of whey proteins, as well as the homogeneity of individual fractions in the process of their obtaining. However, for the precise determination of each fraction content, further researches with the use of whey with a standard quantitative composition of protein fractions are required.

\section{Conclusions}

1. The disc electrophoresis system for acidic proteins in native conditions was chosen on the basis of the com- parison of different electrophoretic systems and the separation efficiency of the basic milk protein fractions, which allows reliable identification of milk protein fractions, in particular, $\beta$-LG, $\alpha$-LA, BSA, PPF and IG.

2. An electrophoresis variant that meets the requirei ments of express analysis (significantly reduced number of required reagents and duration of the analysis) is proposed based on the disc electrophoresis system. At the same time, due to the preservation of the concentrating effect of protein samples in a homogeneous PAG, separation and identification of the basic milk protein fractions ( $\beta$-LG, $\alpha$-LA and BSA), which are the precursors of many known BAPs, are achieved.

3. Simultaneous electrophoresis of whey and casein proteins showed the possibility to detect and identify the basic whey protein fractions ( $\beta$-LG, $\alpha$-LA) in the presence of caseins. The BSA fraction may coincide by electrophoretic mobility with the $\alpha_{\mathrm{S} 1}-\mathrm{CN}-8 \mathrm{P}$ fraction.

4. By the number of identified whey protein fractions in all analyzed samples from 10 batches of milk, the results completely coincide. Four protein fractions ( $\beta-\mathrm{LG}$, $\alpha$-LA, BSA and IG) have been identified. Average values and standard deviations of the relative content of these fractions in 15 whey samples from one milk batch, obtained on the basis of densitometry of three electrophoregrams, were also found to be close: the $\beta-\mathrm{LG}(37.3 \pm 4.2$, $36.5 \pm 2.8,38.3 \pm 2.7), \alpha$-LA $(15.8 \pm 1.5,15.8 \pm 1.3,16.4 \pm 1.1)$, BSA $(8.2 \pm 1.1,8.0 \pm 1,0,9.4 \pm 1.1)$, IG $(17.6 \pm 1.9,17.4 \pm 1.5$, $16.8 \pm 1.5)$. This may testify about a good reproducibility of the method.

\section{References}

1. Hramcov A. G. Fenomen molochnoy syvorotki. Sankt-Peterburg: Professiya, 2011. 804 p.

2. Korhonen H. Milk-derived bioactive peptides: From science to applications // Journal of Functional Foods. 2009. Vol. 1, Issue 2. P. 177-187. doi: https://doi.org/10.1016/j.jff.2009.01.007

3. Iukalo A. V., Datsyshyn K. Ye., Yukalo V. G. Bioactive peptides of the cow milk whey proteins (Bos Taurus) // Biotechnologia Acta. 2013. Vol. 6, Issue 5. P. 49-61. doi: https://doi.org/10.15407/biotech6.05.049

4. Le T. T., Zhao D., Larsen L. B. Analytical Methods for Measuring or Detecting Whey Proteins // Whey Proteins. 2019. P. 155-184. doi: https://doi.org/10.1016/b978-0-12-812124-5.00005-9

5. Nomenclature of the Proteins of Cows' Milk - Sixth Revision / Farrell H. M., Jimenez-Flores R., Bleck G. T., Brown E. M., Butler J. E., Creamer L. K. et. al. // Journal of Dairy Science. 2004. Vol. 87, Issue 6. P. 1641-1674. doi: https://doi.org/10.3168/ jds.s0022-0302(04)73319-6

6. Chemical and functional properties of glycomacropeptide (GMP) and its role in the detection of cheese whey adulteration in milk: a review / Neelima, Sharma R., Rajput Y. S., Mann B. // Dairy Science \& Technology. 2013. Vol. 93, Issue 1. P. 21-43. doi: https:// doi.org/10.1007/s13594-012-0095-0

7. Le T. T., Deeth H. C., Larsen L. B. Proteomics of major bovine milk proteins: Novel insights // International Dairy Journal. 2017. Vol. 67. P. 2-15. doi: https://doi.org/10.1016/j.idairyj.2016.11.016

8. Marnila P., Korhonen H. Milk Proteins: Immunoglobulins // Encyclopedia of Dairy Sciences. 2011. P. 807-815. doi: https://doi.org/ 10.1016/b978-0-12-374407-4.00436-2

9. Korhonen H., Marnila P. Milk Proteins: Lactoferrin // Encyclopedia of Dairy Sciences. 2011. P. 801-806. doi: https://doi.org/ 10.1016/b978-0-12-374407-4.00435-0

10. Brandelli A., Daroit D. J., Corrêa A. P. F. Whey as a source of peptides with remarkable biological activities // Food Research International. 2015. Vol. 73. P. 149-161. doi: https://doi.org/10.1016/j.foodres.2015.01.016

11. Production and characterisation of whey protein hydrolysate having antioxidant activity from cheese whey / Athira S., Mann B., Saini P., Sharma R., Kumar R., Singh A. K. // Journal of the Science of Food and Agriculture. 2015. Vol. 95, Issue 14. P. $2908-2915$. doi: https://doi.org/10.1002/jsfa.7032

12. Characterisation and cytomodulatory properties of peptides from Mozzarella di Bufala Campana cheese whey / De Simone C., Picariello G., Mamone G., Stiuso P., Dicitore A., Vanacore D. et. al. // Journal of Peptide Science. 2009. Vol. 15, Issue 3. P. $251-258$. doi: https://doi.org/10.1002/psc.1093 
13. Dairy Chemistry and Biochemistry / Fox P. F., Uniacke-Lowe T., McSweeney P. L. H., O’Mahony J. A. Springer, 2015. 584 p. doi: https://doi.org/10.1007/978-3-319-14892-2

14. Quantitation of Caseins and Whey Proteins of Processed Milks and Whey Protein Concentrates, Application of Gel Electrophoresis, and Comparison with Harland-Ashworth Procedure / Basch J. J., Douglas F. W., Procino L. G., Holsinger V. H., Farrell H. M. // Journal of Dairy Science. 1985. Vol. 68, Issue 1. P. 23-31. doi: https://doi.org/10.3168/jds.s0022-0302(85)80792-x

15. Yukalo A., Yukalo V., Shynkaryk M. Electrophoretic separation of the milk protein // Proceeding of the International Conference on Bio and Food Electrotechnologies. Compiegne, 2009. P. 227-231.

16. Iukalo A. V. Identification of protein fractions of milk cows casein complex // The Ukrainian Biochemical Journal. 2015. Vol. 87, Issue 4. P. 87-91. doi: https://doi.org/10.15407/ubj87.04.087

17. Yukalo V. G. Obtaining of casein protein complex fractions from cow milk // Nutracos. 2005. Issue 5. P. 17-19.

18. Yukalo V., Datsyshyn K. Gel filtration of cow milk whey proteins // Food Science and Technology. 2019. Vol. 12, Issue 4. P. 72-78. doi: https://doi.org/10.15673/fst.v12i4.1183

19. Kilkisnyi elektroforetychnyi analiz bilkiv kazeinovoho kompleksu / Yukalo V. H., Yavorskyi B. I., Storozh L. A., Solovodzinska I. Ye.// Biolohiya tvaryn. 2007. Vol. 9, Issue 1-2. P. 269-272.

20. Skalka V. V., Savchuk O. M., Ostapchenko L. I. Vyvchennia riznykh form kazeinu u molotsi metodom dysk-elektroforezu // Fizyka zhyvoho. 2010. Vol. 18, Issue 3. P. 36-38.

21. Osterman L. A. Metody issledovaniya belkov i nukleinovyh kislot: Elektroforez i ul'tracentrifugirovanie: prakticheskoe posobie. Moscow: Nauka, 1981. 288 p. 